\title{
Prolonged in vitro cultivation of Ichthyophthirius multifiliis using an EPC cell line as substrate
}

\author{
C. V. Nielsen, K. Buchmann* \\ Department of Veterinary Microbiology, Section of Fish Diseases, Royal Veterinary and Agricultural University, Stigbøjlen 4, \\ 1870 Frederiksberg C, Denmark
}

\begin{abstract}
The ciliate Ichthyophthirius multifiliis, which normally requires a fish host to develop from the theront stage to the trophont stage, was cultivated in vitro for part of its life cycle. Experiments were conducted using a laboratory strain of the parasite originally isolated from rainbow trout Oncorhynchus mykiss in a Danish trout farm. Theronts escaping from tomontocysts were kept in water, cell culture media (E-MEM or L-15), or cultures of EPC (Epithelioma Papulosum Cyprini) cells in plastic tissue culture dishes (Nunc multidish plates). In addition, a 2-compartment system, with water separated from tissue culture media by a monolayer of EPC cells on an Anopore ${ }^{\mathrm{TM}}$ Tissue Culture Insert (mimicking the fish epidermis) was tested as an experimental habitat for the parasite. Theronts transformed into trophonts in all treatments except in water alone. However, development was accelerated in wells containing EPC cells, and survival and growth of trophonts were significantly increased compared to water or tissue culture media alone. Further, the 2-compartment system allowed superior performance of the parasites (attachment of parasites to cells and growth from 36 to $46 \mu \mathrm{m}$ ). In all experiments it was found that the presence of host factors (mucus and serum) stimulated parasite development.
\end{abstract}

KEY WORDS: In vitro culture $\cdot$ Parasite $\cdot$ Ciliate $\cdot$ Ichthyophthirius multifiliis $\cdot$ EPC cells $\cdot$ E-MEM $\cdot$ L-15 Resale or republication not permitted without written consent of the publisher

\section{INTRODUCTION}

The ciliate Ichthyophthirius multifiliis Fouquet, 1876 is an obligate parasite infecting the epidermis of freshwater fish throughout the world (Neresheimer 1908, Buschkiel 1910, Ewing \& Kocan 1992, Matthews 1994, Dickerson \& Dawe 1995). The infective stage (the theront) is attracted by teleost host factors (such as presence of mucus and/or serum) (Lom \& Cerkosovová 1974, Buchmann \& Nielsen 1999) but the parasite needs a live fish for successful development of the trophont stage (Ewing et al. 1985, Ewing \& Kocan 1992). This requirement hampers laboratory propagation of parasite material for various purposes (e.g. vaccine production, experimental studies) unless excessive use is made of live fish for parasite collection and multiplication. Attempts have been made in a few pre-

*Corresponding author. E-mail: kurt.buchmann@vetmi.kvl.dk vious studies to cultivate the parasite in vitro. Hlond (1966) used fish mucus preparations as a substrate for the parasite but did not achieve normal reproduction. Ekless \& Matthews (1993) kept the parasite in water and cell culture media for a limited period without achieving significant development. In the search for a satisfactory culture medium for this ciliate one should select a system mimicking its normal habitat, the epidermis, in the fish. The present work describes the use of an epithelial cell line from carp Cyprinus carpio and the subsequent cultivation of the parasite from the theront stage to the trophont stage in the cell culture.

\section{MATERIAL AND METHODS}

Parasites. Rainbow trout Oncorhynchus mykiss infected with Ichthyophthirius multifiliis were collected from a Danish fish farm (Refsgaard 2). Trophonts were subsequently isolated and added to naive rainbow 
trout in 2001 aquaria with aerated freshwater ( $\mathrm{pH} 7.4$ ) in a temperature-controlled room $\left(11.6^{\circ} \mathrm{C}\right)$ artificially illuminated on a $12 \mathrm{~h}$ light:12 h dark cycle. The fish were fed ad libitum with pelleted feed (Ecoline Biomar).

Isolation of tomontocysts and theronts. Heavily infected fish were anaesthetised in MS-222 (Ethyl-maminobenzoate, methanesulfonate salt $80 \mathrm{mg} \mathrm{l}^{-1}$ ) and killed by cervical dislocation. Fins were cut off and placed in petri dishes with sterile tapwater where free trophonts were allowed to escape from the fins. They developed into tomonts which subsequently encysted to tomontocysts. These were rinsed with Penstrep

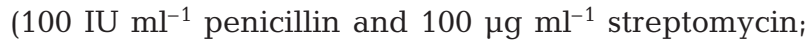
Gibco) and transferred to fresh sterile tapwater $\left(10^{\circ} \mathrm{C}\right)$. Between 43 and $48 \mathrm{~h}$ after the initial isolation of trophonts the theronts were released from the tomontocysts. The theronts were counted in a SedgewickRafter chamber and transferred to different culture media.

Culture media. Monolayers of Epithelioma Papulosum Cyprini (EPC) cells (Fijan et al. 1983) were prepared in 24-well Multidishes (Nunc A/S) with or without Anopore ${ }^{\mathrm{TM}}$ Tissue Culture (TC) Inserts (Whatman) in tissue culture media E-MEM (Eagle's Minimal Essential Medium supplemented with Earle's salt solution; Gibco) or Leibovitz L-15 (Gibco). Both E-MEM and L-15 were supplemented with $5 \%$ foetal calf serum (FCS), penicillin (100 $\mathrm{IU} \mathrm{ml}^{-1}$ ) and streptomycin $\left(100 \mu \mathrm{g} \mathrm{ml}^{-1}\right)$. Seeded cells $\left(4.0 \times 10^{5}\right.$ cells per well and $3.5 \times 10^{5}$ cells per culture insert) were allowed to develop monolayers for 2 to $3 \mathrm{~d}$ prior to experimental use.

Preparation of serum and mucus from rainbow trout. Blood from 2-yr-old rainbow trout was drawn by caudal vein puncture $(4 \mathrm{ml})$. The blood was centrifuged at $3000 \times g$ for 5 min to isolate serum (Biofuge 13; Heraeus/Sepatech). The serum complement was inactivated by heating at $44^{\circ} \mathrm{C}$ for $25 \mathrm{~min}$ (Sakai 1992). Mucus was collected by scraping the skin of the fish with a scalpel. The scrapings were diluted 1:10 in Penstrep and the serum complement in the preparation was inactivated as described above for serum (Sakai 1992).

Experimental design. Two experiments (I and II) were conducted. In Expt I (see Table 1) theronts (15 to 20 well $^{-1}$ ) were incubated (at $15^{\circ} \mathrm{C}$ ) in tapwater $(8$ wells), in E-MEM without EPC cells but supplemented with $5 \%$ FCS (3 wells), in E-MEM with EPC cells and supplemented with $5 \%$ FCS (3 wells), or in E-MEM with EPC cells and supplemented with 5\% FCS, 3\% rainbow trout serum and $1 \%$ rainbow trout mucus (3 wells). Theronts (15 to 20 well $^{-1}$ ) were likewise incubated in L-15 without EPC cells but supplemented with $5 \%$ FCS (6 wells), in L-15 with EPC cells and supplemented with $5 \%$ FCS (6 wells), or in L-15 with EPC cells and supplemented with 5\% FCS, 5\% rainbow trout serum and $5 \%$ rainbow trout mucus ( 6 wells).

In Expt II (see Table 2) $0.2 \mu \mathrm{m}$ Anopore TC Inserts were used for culture of theronts. TC Inserts in all wells were underlain by L-15 medium supplemented with $8 \%$ rainbow trout serum and $8 \%$ rainbow trout mucus. Theronts (15 to 20 well $^{-1}$ ) were incubated in the upper compartment (at $15^{\circ} \mathrm{C}$ ) either in tapwater without EPC cells and not supplemented with $8 \%$ rainbow trout serum and $8 \%$ rainbow trout mucus (4 wells), in tapwater with cells but no serum and no mucus (4 wells), in tapwater with EPC cells and supplemented with $8 \%$ rainbow trout serum and $8 \%$ rainbow trout mucus (4 wells), or in L-15 with EPC cells and supplemented with $8 \%$ rainbow trout serum and $8 \%$ rainbow trout mucus (4 wells).

Examination of viable theronts. The viability and survival of theronts were recorded daily for $14 \mathrm{~d}$ with an inverse microscope (Olympus CK40-F200) (magnification 40-100×) by monitoring ciliary beating (Ekless \& Matthews 1993) and cytological activity (activity of contractile vacuoles).

Size measurement of parasites in cell culture. Parasites in cell culture were studied daily by inverse microscopy and videotaped. The sizes of parasites were then measured on a calibrated monitor showing a still image of the ciliate.

Statistics. The mean sizes of parasites in the different treatments were compared using an analysis of variance (1-way ANOVA) and a level of significance of 0.05 .

\section{RESULTS}

Theronts transformed within $2 \mathrm{~d}$ into trophont-like stages containing a horseshoe-shaped macronucleus in all treatments except in water alone. However, marked differences in morphology and growth were seen between different treatments. When EPC cells were present it was found that parasites in both Expts I and II attached to the cell monolayer and became sessile. In addition the cells reacted in vitro to the presence of the parasites and formed a low cell wall around them. These parasites had a spherical appearance and contained numerous distinctive food vacuoles as well as a horseshoe-shaped macronucleus. Trophont-like cells in media without EPC cells contained no food vacuoles.

\section{Expt I}

The best survival of theronts was found when parasites were cultured in culture media, either E-MEM or 
Table 1. Ichthyophthirius multifiliis. Expt I. Survival of parasites in different media at $15^{\circ} \mathrm{C} .+$ : viable parasites with ciliary beating and cytological activity; -: no living parasites

\begin{tabular}{|c|c|c|c|c|c|c|c|c|c|c|c|c|c|c|}
\hline \multirow[t]{2}{*}{ Medium } & \multicolumn{14}{|c|}{ Time (d) } \\
\hline & 0 & 1 & 2 & 3 & 4 & 5 & 6 & 7 & 8 & 9 & 10 & 11 & 12 & 13 \\
\hline Tapwater & + & + & + & - & & & & & & & & & & \\
\hline E-MEM & + & + & + & + & + & + & + & + & - & & & & & \\
\hline E-MEM with cells & + & + & + & + & + & + & + & + & + & + & - & & & \\
\hline $\begin{array}{l}\text { E-MEM with cells } \\
\text { and serum/mucus }\end{array}$ & + & + & + & + & + & + & + & + & + & + & + & + & - & \\
\hline $\mathrm{L}-15$ & + & + & + & + & + & + & + & + & - & & & & & \\
\hline L-15 with cells & + & + & + & + & + & + & + & + & + & - & & & & \\
\hline $\begin{array}{l}\text { L-15 with cells } \\
\text { and serum/mucus }\end{array}$ & + & + & + & + & + & + & + & + & + & + & + & + & + & - \\
\hline
\end{tabular}

Table 2. Ichthyophthirius multifiliis. Expt II. Survival of parasites in Anopore TC Inserts in different media at $15^{\circ} \mathrm{C}$. The lower compartment medium is L-15 with rainbow trout serum and mucus in all wells. +: viable parasites with ciliary beating and cytological activity; -: no living parasites

\begin{tabular}{|c|c|c|c|c|c|c|c|c|c|c|c|c|c|c|c|}
\hline \multirow{2}{*}{$\begin{array}{l}\text { Medium in upper } \\
\text { compartment }\end{array}$} & \multicolumn{15}{|c|}{ Time (d) } \\
\hline & 0 & 1 & 2 & 3 & 4 & 5 & 6 & 7 & 8 & 9 & 10 & 11 & 12 & 13 & 14 \\
\hline Tapwater, no serum/mucus & + & + & + & + & + & - & & & & & & & & & \\
\hline Tapwater with cells, no serum/mucus & + & + & + & + & + & + & + & + & + & + & + & - & & & \\
\hline Tapwater with cells and serum/mucus & + & + & + & + & + & + & + & + & + & + & + & + & + & + & - \\
\hline L-15 with cells and serum/mucus & + & + & + & + & + & + & + & + & + & + & + & - & & & \\
\hline
\end{tabular}

L-15, supplied with EPC cell monolayers and rainbow trout serum and mucus (Table 1). The maximum survival (12 d) was recorded in L-15 media supplemented with cells and rainbow trout serum and mucus. Parasites cultured on EPC cells had a significantly better survival than those cultured without EPC cells. This survival could be extended significantly by supplementing the wells with rainbow trout serum and mucus. No significant differences in parasite survival were found between treatments supplemented with E-MEM or L-15.

\section{Expt II}

In $0.2 \mu \mathrm{m}$ Anopore TC Inserts the best survival (13 d) was recorded with theronts reared in tapwater on EPC cell monolayers supplemented with rainbow trout serum and mucus (Table 2). The survival of parasites in L-15 and EPC cells supplemented with rainbow trout serum and mucus was significantly better than in the treatment with tapwater without cells or serum or mucus. Parasites reacted to the EPC cells in the same way as in Expt I but showed a significantly better growth of parasite cell size.

\section{Growth of parasites}

Active theronts were structurally pyriform for $2 \mathrm{~d}$ in all media. After $2 \mathrm{~d}$ theronts in media supplemented with serum and mucus developed into spherical parasites. In treatments containing only tapwater or tapwater and EPC cells the parasites remained pyriform until Day 4 after which they too developed into spherical parasites. The parasites in $0.2 \mu \mathrm{m}$ Anopore TC Inserts supplemented with the host factors serum and mucus (in L-15 or tapwater) in the upper compartment had a significantly larger diameter compared to controls (Table 3). Parasites cultured in tapwater with EPC cells only showed no significant size increase. There were no differences in the growth of parasites incubated in tapwater supplemented with serum and mucus compared to parasites incubated in L-15 supplemented with serum and mucus.

\section{DISCUSSION}

Although the trophont of Ichthyophthirius multifiliis is considered an obligate parasite it has been shown in the present study that it is indeed possible to cultivate 
Table 3. Ichthyophthirius multifiliis. Expt II. Size (in $\mu \mathrm{m} \pm \mathrm{SD}$ ) development at $15^{\circ} \mathrm{C}$ of parasites in cell cultures on $0.2 \mu \mathrm{m}$ Anopore TC Inserts. The lower compartment medium is L-15 and rainbow trout serum and mucus in all wells ( $\mathrm{n}=20$, unless otherwise stated). nm: parasites were not spherical and could not be measured and compared to the other groups. ${ }^{*}$ Size is significantly larger than control (tapwater) $(\mathrm{p}<0.05) ;{ }^{* *}$ size is significantly larger than tapwater with EPC cells $(\mathrm{p}<0.05) .{ }^{\mathrm{a}} 3<\mathrm{n}<20$; ${ }^{\mathrm{b}}$ only 1 viable parasite left. -: no living parasites

\begin{tabular}{|c|c|c|c|c|c|c|c|c|c|c|c|c|c|}
\hline $\begin{array}{l}\text { Medium in upper } \\
\text { compartment }\end{array}$ & 2 & 3 & 4 & 5 & 6 & 7 & $\begin{array}{c}\text { Time }(\mathrm{d}) \\
8\end{array}$ & 9 & 10 & 11 & 12 & 13 & 14 \\
\hline Tapwater & $\mathrm{nm}$ & $\mathrm{nm}$ & $\begin{array}{r}30.3 \\
\pm 4.5\end{array}$ & $\begin{array}{l}33.4 \\
\pm 5.2\end{array}$ & $\begin{array}{r}32.6 \\
\pm 2.8\end{array}$ & - & & & & & & & \\
\hline Tapwater with cells & $\mathrm{nm}$ & $\mathrm{nm}$ & $\begin{array}{c}32 \\
\pm 3.5\end{array}$ & $\begin{array}{r}32.3 \\
\pm 3.3\end{array}$ & $\begin{array}{r}31.7 \\
\pm 2.1\end{array}$ & $\begin{array}{r}30.6 \\
\pm 2.7\end{array}$ & $\begin{array}{r}28.9 \\
\pm 2.1\end{array}$ & $\begin{array}{l}29.7^{\mathrm{a}} \\
\pm 5.2\end{array}$ & $31.43^{\mathrm{b}}$ & - & & & \\
\hline $\begin{array}{l}\text { Tapwater with cells } \\
\text { and serum/mucus }\end{array}$ & $\begin{array}{c}36^{\mathrm{a}} \\
\pm 5.2\end{array}$ & $\begin{array}{l}36.6 \\
\pm 2.7\end{array}$ & $\begin{array}{l}35.1 \\
\pm 3.3\end{array}$ & $\begin{array}{c}40 \\
\pm 6.2 \\
*, * *\end{array}$ & $\begin{array}{l}43.7 \\
\pm 6.2 \\
*, * *\end{array}$ & $\begin{array}{c}45.4 \\
\pm 8.0 \\
* *\end{array}$ & $\begin{array}{c}42.9 \\
\pm 8.6 \\
* *\end{array}$ & $\begin{array}{c}43.3 \\
\pm 7.9 \\
* *\end{array}$ & $\begin{array}{c}44.4 \\
\pm 9.7\end{array}$ & $\begin{array}{l}43.3^{\mathrm{a}} \\
\pm 8.6\end{array}$ & $\begin{array}{c}40.7^{a} \\
\pm 11.3\end{array}$ & $28.6^{\mathrm{b}}$ & - \\
\hline $\begin{array}{l}\text { L-15 with cells } \\
\text { and serum/mucus }\end{array}$ & $\begin{array}{l}36.6^{\mathrm{a}} \\
\pm 2.4\end{array}$ & $\begin{array}{r}36.9 \\
\pm 2.7\end{array}$ & $\begin{array}{c}36 \\
\pm 2.8\end{array}$ & $\begin{array}{l}40.3 \\
\pm 5.8 \\
*, * *\end{array}$ & $\begin{array}{l}43.1 \\
\pm 4.9 \\
*, * *\end{array}$ & $\begin{array}{c}42.9 \\
\pm 5.0 \\
* *\end{array}$ & $\begin{array}{c}42.7 \\
\pm 7.8 \\
* *\end{array}$ & $\begin{array}{c}45.5^{\mathrm{a}} \\
\pm 6.4 \\
* *\end{array}$ & $\begin{array}{c}45^{\mathrm{a}} \\
\pm 11.5 \\
* *\end{array}$ & - & & & \\
\hline
\end{tabular}

this stage in vitro by mimicking a number of conditions found in the host epidermis. The present work showed that theronts will transform into trophonts if suitable substrates are present, and the subsequent survival of the parasites without hosts can even be extended to $13 \mathrm{~d}$. It was found that the presence of epithelial cells from fish (EPC cells) improved the transformation of theronts into trophonts. Likewise, in the presence of EPC cells, the feeding of the parasite was superior compared to feeding in culture medium alone. Thus, food vacuoles were abundant in the cytoplasm of the parasites with access to EPC cells. Indeed significant growth of the trophonts was seen in the system containing EPC cells. Ekless \& Matthews (1993) studied in vitro culture using media without cells. They also found that such media will only prolong survival but not initiate proper development or growth of the theronts or trophonts. We found that host factors such as fish mucus and serum will affect the behaviour of the trophonts. Thus, the trophonts were only shown to attach to the monolayer of EPC cells if these host factors were present. This corresponds to previous studies showing the convincing chemoattractive effect of such host molecules on theronts (Lom \& Cerkosovova 1974, Buchmann \& Nielsen 1999) and points to mucus and serum as an indispensable part of the substrate. Mucus alone in an aqueous solution was used by Hlond (1966) as substrate in attempts to cultivate the parasite. The results obtained in those experiments are not readily analysable but indicate that mucus alone is not sufficient for cultivation of the parasite, a conclusion which is supported by our control groups. Superior parasite growth was observed when tissue culture inserts were used in the wells. Such a system allowed the use of a 2-compartment system (freshwater/tissue culture medium) separated by an artificial epithelium (the EPC cell monolayer). This system partly mimics the fish epidermis (freshwater environment separated from the body compartment by the fish skin). Thus, it is indicated that different osmotic conditions present on the 2 sides of the epithelial barrier is one of several factors which should be included in further studies on the cultivation of trophonts in vitro. It is therefore indicated that trophonts are able to detect changes in osmotic conditions on 2 sides of an epithelium. This suggestion is further supported by in situ studies by Matthews et al. (1996) and Wahli \& Matthews (1999), who showed that trophonts escape from their host when these are immersed into tissue culture medium (MEM).

Further studies aiming at a successful in vitro cultivation of the complete life cycle of Ichthyophthirius multifiliis are needed. It is known that freshwater fish are able to respond immunologically to infection with this ciliate. Both specific and non-specific immunological reactions involving the humoral and cellular systems occur in these host reactions (Hines \& Spira 1974, Graves et al. 1985, Wahli \& Meier 1985, Burkart et al. 1990, Cross \& Matthews 1992, Sin et al. 1996, Clark \& Dickerson 1997, Buchmann et al. 1999). Therefore, the production of a vaccine against this pathogenic parasite is conceivable. Although vaccination using recombinant vaccines (He et al. 1997) could show promise, it would be beneficial to have access to abundant parasite material which could facilitate the production of a traditional vaccine composed of native parasite antigens. This can only be achieved through labour-intensive parasite collection from infected fish or by in vitro culture of the ciliate. The present results show that the final part of the life cycle (encystment of tomonts and tomite formation) is still to be achieved in vitro. Suc- 
cessful encystment and theront production is partly a function of trophont size (Ewing et al. 1986). Thus it is suggested that by optimising the culture conditions and securing better trophont growth the final part of the life cycle could also be conducted without a host.

Acknowledgements. This work was supported by the Danish Ministry of Food, Agriculture and Fisheries (FISK97).

\section{LITERATURE CITED}

Buchmann K, Nielsen ME (1999) Chemoattraction of Ichthyophthirius multifiliis (Ciliophora) theronts to host molecules. Int J Parasitol 29:1415-1423

Buchmann K, Lindenstrøm T, Sigh J (1999) Partial cross protection against Ichthyophthirius multifiliis in Gyrodactylus derjavini immunized rainbow trout. J Helminthol 73: 189-195

Burkart MA, Clark TG, Dickerson HW (1990) Immunization of channel catfish, Ictalurus punctatus Rafinesque, against Ichthyophthirius multifiliis (Fouquet): killed versus live vaccines. J Fish Dis 13:401-410

Bushkiel AL (1910) Beiträge zur Kenntnis des Ichthyophthirius multifiliis Fouquet. Arch Protist 21:61-102

Clark TG, Dickerson HW (1997) Antibody-mediated effects on parasite behavior: evidence of a novel mechanism of immunity against a parasitic protist. Parasitol Today 12: 581-594

Cross ML, Matthews RA (1992) Ichthyophthiriasis in carp, Cyprinus carpio L.: fate of parasites in immunized fish. J Fish Dis 15:497-505

Dickerson HW, Dawe DL (1995) Ichthyophthirius multifiliis and Cryptocaryon irritans (Phylum Ciliophora). In: Woo PTK (ed) Fish diseases and disorders - protozoan and metazoan infections, Vol 1. CAB International, Wallingford, p181-227

Ekless LM, Matthews RA (1993) Ichthyophthirius multifiliis: axenic isolation and short-term maintenance in selected monophasic media. J Fish Dis 16:437-447

Ewing MS, Kocan KM (1992) Invasion and development strategies of Ichthyophthirius multifiliis, a parasitic ciliate of fish. Parasitol Today 8(6):204-208

Ewing MS, Kocan KM, Ewing SA (1985) Ichthyophthirius

Editorial responsibility: Wolfgang Körting,

Hannover, Germany multifiliis (Ciliophora) invasion of gill epithelium. J Protozool 32(2):305-310

Ewing MS, Lynn ME, Ewing SA (1986) Critical periods in development of Ichthyophthirius multifiliis (Ciliophora) populations. J Protozool 33(3):388-391

Fijan N, Sulimanovic D, Bearzotti M, Muzinic D, Zwillenberg LO, Chilmonczyk S, Vautherot JF, de Kinkelin P (1983) Some properties of the Epithelioma Papulosum Cyprini (EPC) cell line from carp Cyprinus carpio. Ann Virol (Inst Pasteur) 134E:207-220

Graves SS, Evans DL, Dawe DL (1985) Mobilization and activation of non-specific cytotoxic cells (NCC) in the channel catfish (Ictalurus punctatus) infected with Ichthyophthirius multifiliis. Comp Immunol Microbiol Infect Dis 8:43-51

He J, Yin Z, Xu G, Gong Z, Lam TJ, Sin YM (1997) Protection of goldfish against Ichthyophthirius multifiliis by immunization with a recombinant vaccine. Aquaculture 158:1-10

Hines RS, Spira DT (1974) Ichthyophthiriasis in the mirror carp Cyprinus carpio (L.), V. Acquired immunity. J Fish Biol 6:373-378

Hlond (1966) Experiments in in vitro culture of Ichthyophthirius. FAO Fish Rep 44(5):365-368

Lom J, Cerkosovová A (1974) Host-finding in invasive stages of Ichthyophthirius multifiliis. J Protozool 21:457

Matthews RA (1994) Ichthyophthirius multifiliis Fouquet, 1876: infection and protective response within the fish host. Pike AW, Lewis JW (eds) Parasitic diseases of fish. Samara Publ Ltd, Tresaith, p 17-42

Matthews RA, Matthews BF, Ekless LM (1996) Ichthyophthirius multifiliis: observations on the life-cycle and indications of a possible sexual phase. Folia Parasitol 43:203-208

Neresheimer E (1908) Der Zeugungskreis des Ichthyophthirius. Ber Biol Versuchsstat München 1:165-184

Sakai DK (1992) Repertoire of complement in immunological defense mechanisms of fish. Annu Rev Fish Dis 2:223-247

Sin YM, Ling KH, Lam TJ (1996) Cell-mediated immune response of goldfish, Carassius auratus (L.), to Ichthyophthirius multifiliis. J Fish Dis 19:1-7

Wahli T, Matthews RA (1999) Ichthyophthiriasis in carp Cyprinus carpio: infectivity of trophonts prematurely exiting both the immune and non-immune host. Dis Aquat Org 36:201-207

Wahli T, Meier W (1985) Ichthyophthiriasis in trout: investigations of natural defence mechanisms. In: Ellis AE (ed) Fish and shellfish pathology. Academic Press, London, p 347-352

Submitted: February 17, 2000; Accepted: June 26, 2000

Proofs received from author(s): August 21, 2000 